\title{
Building Information Modeling and Sustainable Architecture Design Analysis
}

\author{
Shaojie Zhang ${ }^{1}$ Tieqiao Xiao ${ }^{2}$ \\ ${ }^{1,2}$ Department of Architecture \& Urban Planning, \\ Anhui University of Architecture, Hefei, China, 230022
}

\begin{abstract}
Green buildings and sustainable design have become the points architects are concerned about. At the same time, with the design and construction of architectural projects becoming more and more complicated, Building Information Modeling (BIM) plays a more important role in the architectural process of aiming to create green buildings and high performance buildings. It can create collaboration between other disciplines that has not occurred in traditional design before. This paper will focus on several case studies, which will be presented and analyzed to offer specific evidence in practice that BIM is the key to realizing sustainable architectural development.
\end{abstract}

Keywords: BIM; Architecture Design; Green building

\section{Introduction of BIM (Building Information Model)}

Designing and delivering more sustainable projects can be complex. It requires close coordination across different project stages, from design through construction and operation. Many firms are looking for the best way to integrate building information modeling (BIM) technology with sustainable design and analysis tools. BIM is core to Autodesk's sustainable design approach for building performance analysis and simulation.
BIM enables architects and engineers to use digital design information to analyze and understand how their projects perform before they are built. Developing and evaluating multiple alternatives at the same time enables easy comparison and informs better sustainable design decisions.

BIM also includes the information of construction progress and process and building protection and management. So BIM not only can be used in building the intuitionistic model but can also provide a reasonable managing environment, which lets all attended professionals, and managing staffs share all building information efficiently.

\section{Case study1: Sidwell friends middle school}

\subsection{Introduction}

The success of this LEED Platinum project is based on the following integrated design ideas and BIM tool since the project start. After the cooperating of landscape architect, wetland consultant and other related professionals, the team respected and preserved the sensitive environmental site. Furthermore the team carry forward the ecological value of this site, by introducing the concept of wetland into the urban context, the perfect meeting of the old building's renovation and new building's addition in the wetland courtyard revitalize "this 55-year-old middle school and the building itself 
become an instructive and convincing teacher".

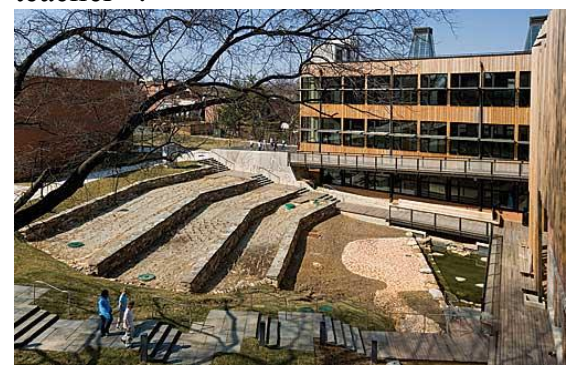

Figure 1: Sidwell friends middle school (Fortmeyer, 2007)

\subsection{Site and project description}

The campus of Sidwell Friends Middle School sits at two watersheds Rock Creek and Glover Archbold watershed in Washington, D.C.; both watersheds have significant ecological value. This kind of sensitive environmental site provides whole team endless inspirations. This project was completed in September 2006, the functional space include classrooms, library, art/music rooms, science labs, constructed wetland, rooftop container garden.

\subsection{Renovation and expandation}

When Philadelphia-based Kieran Timberlake Associates (KTA) accepted this project, updating and expanding the 55-year-old middle school was the first priority. The design team renovated the existing 33,000 square-foot building and expanded it with a 39,000-square-foot addition.

The team pays attention to wastewater management since the start of the project, however how and what kind of way is best evolved in a long time. Firstly, they try to take use the general idea of a putting wastewater in a Living Machine in which wastewater will be treated in a series of tanks, which is typically housed in a greenhouse. But regenerative-design consultant Bill Reed, AIA, argued "a
Living Machine is just another piece of equipment to fix a problem that we created." Reed suggested the constructed wetland that became the centerpiece of the courtyard.

Wastewater from the kitchen and bathrooms flows into settling tanks, where solids are collected before the water is released below the surface of the constructed wetland. After about 10 years, the solids will have to be removed to a landfill or composted, according to landscape architect Reed.

The wetland occupies a series of terraces in the courtyard-premium space the architects argued should be used as much for teaching purposes as for lessening the building's water use. Opened in fall 2006, the expansion uses 90 percent less water than comparable buildings (Fortmeyer, 2007).

\subsection{The role of Landscape Architect in Wetland design}

Following the sustainable idea, landscape architect José Alminana of Andropogon of Philadelphia explains the central wetland is not only a water-management system but also has multiple landscape functions. It begins with green roof areas that retain rainwater and also serve as garden space in which students grow vegetables for the cafeteria. In addition to the wetland, the designers introduced more than 80 plant species, all native to the Chesapeake Bay region which increase the biodiversity in this wetland ecosystem.

\subsection{Other green design ideas}

Several design factors contribute to the building's energy economy. Sitting and orientation of the building optimize the use of daylight. Solar chimneys are designed for mechanically assisted natural ventilation to minimize the need for artificial cooling. South-facing 
glazing at the tops of the shafts heat the air within, creating a convection current which draws cooler air in through northfacing open windows. Classrooms were designed to optimize natural lighting as the primary daytime illumination source (Kieran Timberlake Associates LLP, 2007).

The control of water guided other design decisions. For example, the exterior cladding is a rain screen system that includes a ventilated cavity to resist water intrusion. Interior finishes include cork, linoleum, bamboo, and wood flooring remilled from pilings extracted from Baltimore Harbor. Building materials are reused, including reclaimed wood for the façade.

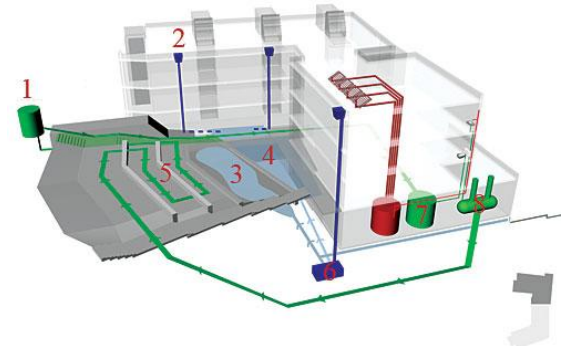

1. Trickle filter 5. Constructed

wetland

2. Roof drain leaders

3. Bioretention pond 6. Rainwater

7. Gray-water cistern

4. Biology pool

8. Primary treatment tank

Figure 2: Functional areas and facilities in Sidwell friends middle school ( Fortmeyer, 2007)

\subsection{Evaluation}

Sidwell's wetland was instigated by the project's environmental consultant, Bill Reed, but was designed with the guidance of Michael Ogden, a wetland expert and civil engineer with Natural Systems in Santa Fe, New Mexico. "We don't normally think of wastewater-treatment systems as architectural elements," (Fortmeyer, 2007) Ogden says, cognizant of the fact that generations of students passing through the school will now have first-hand experience with a process otherwise invisible in the urban landscape.

The goal of green design guild whole team focusing on performance rather than a traditional aesthetic which can be found in devoting the building's central courtyard to a constructed wetland rather than a lawn and some other designs. With every team member working together, they reached agreement in the end. This green building obviously transforms the image of the school culturally and operationally.

\section{Case study 2: SOFLO studio}

\subsection{The site and project background}

The site belongs to the brown field, which was originally owned by a family business that built truck trailers, but more recently had been used as a junkyard. The Architects in the OCO and Alamo worked together to reclaim two warehouses into their studios in San Antonio's SoFlo (South Flores Street) neighborhood. The buildings had good bones and what's more, the site was located in SoFlo, just a half-mile south of downtown San Antonio. With a right price, OCO and Alamo Architecture firm working together purchase the old junkyard and renovate it into their studios.

\subsection{Urban infill development}

About the "urban infill" ideas, Alamo Architects give a specific explanation. They work to engage the pedestrian ways adjacent to our structures, with shade, friendly night lighting, and lively retail storefronts. As a result, "even a building as functional as a parking garage can be a good neighbor" (Alamo architects, 2008). 


\subsection{Landscaping}

Vegetated areas feature mostly native species that require little water. Close to the southern courtyard's pond, however, the landscape architect designed an oasis with almost jungle, tropical plants. In the lawn areas, he used zoysia, a grass that needs trimming only a couple of times each year. When it's not cut, it develops a beautiful wave feature.

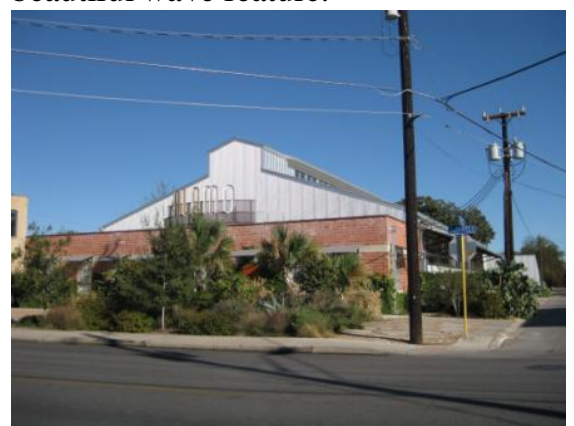

Figure 3: Facade of Soflo Office Studios (Zhang,2011)

\subsection{Rainwater collection \& Water Conservation}

The firms used crushed granite in place of paving. In this building, a 6,500-gallon cistern collects Alamo's air-conditioner condensate as well as rainwater from half its roof. This cistern supplies water for the pond and much of the irrigation needs. The project uses 80 percent less potable water for irrigation than a project with conventional plantings and irrigation (Boehland, 2008).

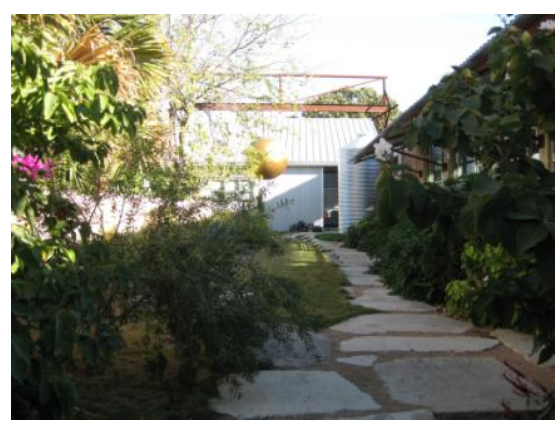

Figure 4: Broken Concrete Slabs as Pavers (Zhang, 2011)

\section{The third part: Conclusion}

During the process toward the popularization of integrated design, we should also consider some key issues, which may influence the development of integrated design.

(1) Interdisciplinary cooperation: The form and effect of interdisciplinary cooperation is the key and also the most important issue influencing the realization of integrated design. The difficulty of organizing cooperation is imaginable and the form of cooperation is diversified. Only a well-organized and high efficient team can realize the final aim of integrated design.

(2) Higher requirement to Architect: Architect is the leader in whole team with integrated design. This gives a higher requirement to the whole information structure of architect. The existing architecture education still has great deficiency which most focus on single architecture field. The ability of architect in organization, management and knowledge of other related disciplines is insufficient to fit the task of leading whole integrated design team.

(3) The education of existing professionals: integrated design is a brand new mode; it will be hard for designers who used to traditional design way. Especially all kinds of BIM softwares, it needs input a lot of time and money to learn that.

(4) About BIM softwares, there are many kinds of softwares which include the assistant design, energy environment imitation and evaluation and many types of database. These softwares maybe are enough for the imitation and design in each period during whole integrated design process, however when and how 
make sure to use them efficiently is still unclear.

Integrated design is based on the information sharing and edit commonly and BIM is the only design media for integrated design. It integrates all the information data in whole building's lifecycle into one single building information model. It transfers all different ideas from related professionals into data information and saves in the computer, which let different designers do different design in the same time.

Based on this point, throughout the building process, BIM is a very helpful tool to help select the best design concept, the best running way in building construction and maintenance period; introduce the attendance of designers in building's whole life period (Zhang and Wang, 2009). By the whole team cooperation and BIM, the design process can go on smoothly and efficiently. It reduces the cumulative cost significantly and saves energy in building's whole lifecycle period.

By taking use of the high efficiency merit of computer, as soon as any data are changed the according data will be changed too, which reduce the working hours comparing with traditional design method. And designer also can use this vivid computer model communicate with the customer in different design periods.

When depending on the single BIM as tool, due to the deficiency of software, the designer sometime cannot go on with the simulation and evaluation such as some software doesn't include the new material which will limit new material use in architecture design.

BIM is a tool, and it cannot replace the brain thinking. Just like the first revolution in architecture even computer drawing become more popular, it still cannot replace hand drawings and sketches, the same as physical model has a unique charming than computer drawing. Especially in the start design period, sketches and physical model will be more helpful in the creation of design ideas.

\section{REFERENCE}

[1] Allen, Edward. How Buildings Work: The Natural Order of Architecture.3rd ed. Oxford University Press, 2005.

[2] Doerfler, James,. \& Dong, Kevin. Teaching Integrated Practice in a Cross-Disciplinary Curriculum after Two Years, 2009.

[3] Feng and Zhang. Integrated design method and process aiming at saving energy in building. The Journal of Architecture, 2009.

[4] Flint, Anthony. Green meets history in annex. The Boston Globe, 2004.

[5] Graham, Peter. Building Ecology: First Principles for a Sustainable Built Environment. Hoboken, NJ: John Wiley \& Sons, 2007.

[6] Hartog, Harry den. City within City (M. Hou, Trans.) China. Indoor Design and Decoration, 2009.

[7] Keeler, Marian. Fundamentals of Integrated Design for Sustainable Building. NJ: John Wiley \& Sons, 2009.

[8] Nattrass, B., \& Altomare, M. The natural step for business. Gabriola Island, BC: New Society Publishers, 1999.

[9] Russ, Randall and Dickinson, Joan. Collaborative Design: "Forming, Storming, and Norming". Interior Design 25(2), p52-58, 1999.

[10] http://greensource.construction

[11] http://www.alamoarchitects.com 